\title{
ストーマ造設に際しての手技上の工夫
}

\author{
渋谷均 小出眞二 黒川 城司 沖田 憲司 \\ 市立室蘭総合病院外科
}

\begin{abstract}
セルフケアが容易で, 合併症のないストーマを造設することは患者の QOL 上極めて重要で ある. ストーマの形態としては, 高齢者のオストメイトの増加を考慮し, 洗腸療法, 自然排便 法の双方に対応できる突出型のストーマを造設しておくのが良い。それでも皮膚切開の大きさ や, 挙上腸管の長さ, 縫合法などにより術後のストーマの形状はさまざまである. 著者らは過 去 7 年間, 20 例の単孔式結腸ストーマ造設に際し, 皮虐切開の大きさ, 挙上腸管の長さを測 定し, その結果としてのストーマの最大径, 高さを計測してきた. 種々の検討の結果, 皮膚切 開は $2.5 \times 1.5 \mathrm{~cm}$ (縦 $\times$ 横), 挙上腸管の長さを $3.0 \sim 3.5 \mathrm{~cm}$ とすると, ストーマの最大径は 2.5 $\mathrm{cm}$, 高さ $1 \mathrm{~cm}$ 程度の円形のストーマが造設され満足しうる結果を得た.
\end{abstract}

索引用語 : 直腸癌, 人工肛門造設術

はじめに

近年, 大腸癌は増加傾向にあり, この原因とし て食習慣の変化, とくに動物性脂質摂取量の増加 が注目されている。また高齢化社会を迎え高齢者 の大腸癌患者が増加している点もあげられる。下 部直腸癌の手術では技術の向上, また器械吻合に よる超低位での吻合が可能になったこともあり， 直腸切断. 人工肛門造設術は以前に比較してかな り減少傾向にある。しかしながら, 歯状線に近い 癌ではやむを得ず人工肛門（以下，ストーマと略 す）を造設せざるを得ない症例も見受けられる。 これらの症例に対し, より良いストーマ造設を行 うために, 手術に際し, 皮膚切開 (以下, 皮切と 略す）の大きさ, 挙上腸管の長さ, 吻合法などに ついて種々の試みをしてきたのでその結果につい て報告する。

\section{I. 対象と方法}

1992 年 11 月にストーマ外来を開設して以来, 1993 年から 1998 年末までに下部直腸癌に対し造
設した単孔式結腸ストーマ 20 例を対象とした。 当初はストーマの高さに主眼をおいたため, 皮切 もやや大きく，挙上腸管も長いものが多い.

手術方法としては約 1 週間前, 患者との話し合 いで十分なインフォームドコンセントを得たあと， 基本的にCleveland Clinic の基準，1）臍よりも 低い位置，2）腹部脂肪層の頂点，3）腹直筋を貫 く位置, 皮膚の窪み, 㱀, 㓔痕, 上前腸骨棘の近 くを避けた位置, 4) 本人がみることができセル フケアのしやすい位置, に従ったストーマサイト マーキングを行うが, 実際には患者の状況に応じ てこれらの基準点と若干異なる位置に造設される こともある.

皮切予定部位はスケールを用い, 皮切の長さを 計測してから縦長に楕円形のデザインを行い皮切 を加えている。ストーマは横に広がるので切開線 としては縦長にしておくのが良い. 皮下脂肪は切 除せず電気メスで鋭的に切開を加え, 腹直筋の前 鞘に達した後, 約 $2.5 \mathrm{~cm}$ の縦切開を加える. 挙上 腸管は後腹膜経由とし, 腹直筋後鞘まで用手的に 鈍的に剥離した後, 前方から腹直筋筋束を分け入 


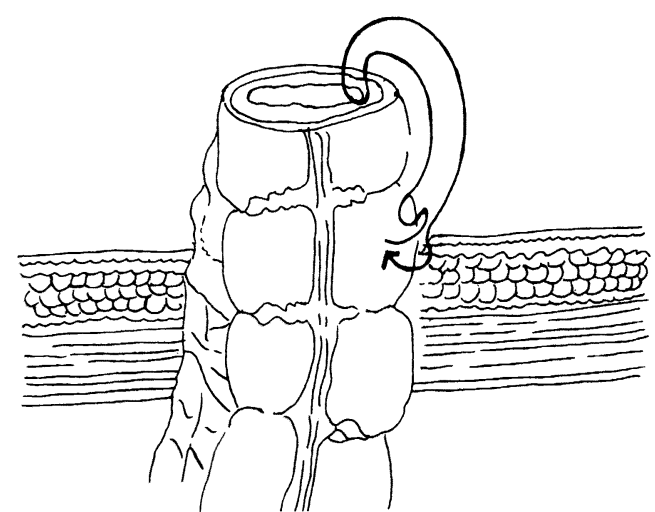

図 1 腸間の外反固定 atraumatic 針付き吸収糸を用い, 腸間の漿膜，粘 膜，皮膚の真皮の順に系を通し，埋没縫合とする。

り，後鞘を切開し，両者を貫通させる．挙上腸管 は緊張のかかからないこと，また腸管断端の血流 が十分であることを確かめてルート内を通過させ， 皮膚上方に持ち上げる. 挙上腸管は若干長めにと り, 腸間の漿膜と腹直筋前鞘は 4 針で縫合固定す る。その後，皮膚レベルから挙上腸管断端までの 長さを $3 \sim 3.5 \mathrm{~cm}$ となるように余分な腸管を切離 し, atraumatic 針付き吸収系を用いて，腸管の 漿膜, 断端の粘膜, 皮膚の真皮に糸をかけ, 埋没 縫合とする（図 1)。この際，腸間膜の脂肪組織 はそのままとし, trimmingはせず，なかに押し 込むようにする。結果として皮膚面が若干盛り上 がるようになるが，月日が経てば皮膚面は平坦に なる．全周で約 12 針で縫合が終了するが，脂肪 組織がはみ出すようであれば縫合を追加する。

\section{結＼cjkstart果}

ストーマの大きさ，高さはいずれも術後 1 年以 上経過してからストーマ外来で計測した。皮切の 長さ (縦×横) とストーマの大きさ (縦 $\times$ 横) の 平均値は皮切 $3.0 \times 2.0 \mathrm{~cm}$ では $2.6 \times 3.1 \mathrm{~cm}$, 皮切 $2.5 \times 2.0 \mathrm{~cm}$ では $2.4 \times 2.7 \mathrm{~cm}$, 皮切 $2.5 \times 1.5 \mathrm{~cm}$ で は $2.3 \times 2.6 \mathrm{~cm}, 2.0 \times 1.0 \mathrm{~cm}$ では $2.2 \times 2.4 \mathrm{~cm}$ であっ た（表 1 ).

挙上腸管の長さとストーマの高さの平均值では 挙上腸管の長さ $1.5 \sim 2.5 \mathrm{~cm}$ では高さ $0.6 \mathrm{~cm}$, $3.0 \sim 3.5 \mathrm{~cm}$ では $1.0 \mathrm{~cm}, 4.0 \sim 4.5 \mathrm{~cm}$ では $1.3 \mathrm{~cm}$, $5 \mathrm{~cm}$ では $2.2 \mathrm{~cm}$ であった（表 2 ).
表 1 皮虐切開とストーマの最大径

\begin{tabular}{cc}
\hline $\begin{array}{c}\text { 皮切の長さ } \\
(\text { 縦 } \times \text { 横, } \mathrm{cm})\end{array}$ & $\begin{array}{c}\text { 最大径 } \\
(\mathrm{cm}, \mathrm{M} \pm \mathrm{SD})\end{array}$ \\
\hline $3.0 \times 2.0(7$ 例 $)$ & $3.1 \pm 0.2$ \\
$2.5 \times 2.0(6$ 例 $)$ & $2.7 \pm 0.1$ \\
$2.5 \times 1.5(6$ 例 $)$ & $2.6 \pm 0.4$ \\
$2.0 \times 1.0(1$ 例 $)$ & $2.4 \pm 0$ \\
\hline
\end{tabular}

表 2 挙上腸管の長さとストーマの高さ

\begin{tabular}{cc}
\hline $\begin{array}{c}\text { 挙上腸管の長さ } \\
(\mathrm{cm})\end{array}$ & $\begin{array}{c}\text { ストーマの高さ } \\
(\mathrm{cm}, \mathrm{M} \pm \mathrm{SD})\end{array}$ \\
\hline $1.5 \sim 2.5(5$ 例 $)$ & $0.6 \pm 0.1$ \\
$3.0 \sim 3.5(6$ 例 $)$ & $1.0 \pm 0.3$ \\
$4.0 \sim 4.5(5$ 例 $)$ & $1.3 \pm 0.3$ \\
$5.0 \quad(4$ 例 $)$ & $2.2 \pm 0.3$ \\
\hline
\end{tabular}

\section{III. 考 察}

ストーマ外来を開設以来，受診した患者の平均 年齢は 70 歳を越えており, このうち 70 歳以上の 患者の多くが自然排便法を行っている，ストーマ 外来の開設が一つの契機となり，より良いストー マを作るための努力をしてきたが，七ルフケアが しやすく，合併症のないストーマを造設するには どのような工夫が必要かを考えてきた。文献，教 書を紐解いても造設法は述べられているが，その 結果としてストーマの形状や大きさの詳しい記載 はない ${ }^{1-4)}$. 外来で患者を診察し，ストーマケア について話し合いを深めていくとストーマの大き さについては $2.5 \mathrm{~cm}$ 位が良いと思われる。大きめ のストーマは面板が大きくなるため小柄の人では 貼付上都合が悪く，またより小さめのストーマで は将来的に狭小化した場合にその対応に苦慮する ことがある。ストーマの高さではあまり高いと見 た目が悪く，またストーマ袋と密に接触するため 便の下方への落ちが悪くなる，逆に低すぎると便 漏れによる皮膚トラブルの心配がある。いずれに しろ面板を貼付しても便漏れがない高さが必要で $1.0 \mathrm{~cm}$ 位になるような挙上腸管の長さが必要であ る. 皮切について柴崎ら ${ }^{5)}$ は, 直径 $20 \mathrm{~mm}$ で行っ た 47 例では $59.6 \%$ がストーマサイズ, $25 \sim 30 \mathrm{~mm}$ に分布したと述べ，比較的小さな皮切が良いとし ている，著者らの検討でも，皮切の大きさは 


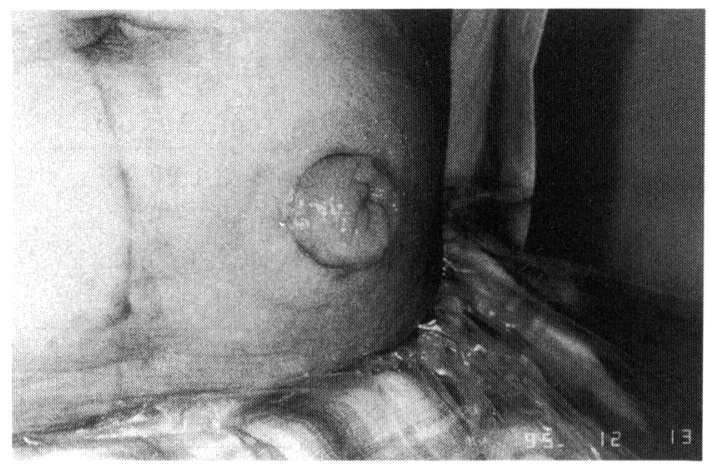

図 2 皮切 $2.5 \times 1.5 \mathrm{~cm}$, 挙上腸間 $3 \mathrm{~cm}$, 結果 2.3 $\times 2.6 \times 1.1 \mathrm{~cm}$ (縦, 横, 高さ).

$2.5 \times 1.5 \mathrm{~cm}$ が良く，また挙上腸管の長さは 3〜 3.5 cm にすると, 結果として最大径 $2.5 \mathrm{~cm}$, 高さ $1 \mathrm{~cm}$ 程度の円形のストーマが造設される. 図 2 は皮切 $2.5 \times 1.5 \mathrm{~cm}$, 挙上腸管 $3 \mathrm{~cm}$ で出来上 がりのストーマは $2.3 \times 2.6 \times 1.1 \mathrm{~cm}$ （縦 $\times$ 横 $\times$ 高 さ）のストーマである。

手術に際しては直腸切断後, ストーマ造設時, 患者の QOL を考慮し，より良い久トーマ造設を 目指しているが，術後早期には理想的なストーマ ができ上がったと思っても数力月，数年を経てス トーマを観察すると, 患者の状況によっては肥満 傾向を示し，ストーマが皮膚面より陥没しており， セルフケアがしずらくなっている症例も見受けら れる。このような患者では術前の体重を把握して おき, 将来的に体重増加が見込まれる患者では挙
上腸管を少し長めにとり，ストーマを高めにして おく工夫が必要である。ストーマの合併症として 最も多いのは皮膚障害であるが，この原因として はストーマの造設位置や，形が不適切であったり ストーマの高さがなく便漏れによるものが多い. しかしながら，良いストーマを造設しておけば, これらの原因による皮虑障害はまずないと言って 良い。むしろ皮膚障害は皮膚保護材によるアレル ギーが原因であることが多く，ストーマ外来で長 期的に患者を経過観察することが必要である。

$$
\text { おわりに }
$$

良いストーマを作るためには皮切の大きさ，挙 上腸管の長さを考慮し，また吸収系を用いた真皮 下の埋没縫合が必要であり, 結果としてセフケア が容易な良いストーマが造設される。

\section{文献}

1）穴沢貞夫，片山隆市，石田秀世ほか：ストーマ造設 上の工夫. 臨外 $41: 1759-1767,1986$

2）森田隆幸，今 充，山中祐治 : 永久的結腸人工肛門 の造設法と管理. 手術 48: 975-982, 1994

3）畠山勝義：人工肛門造設術。消外 $18: 1028-1036$, 1995

4）亀岡信悟, 板橋道朗：人工肛門造設術.消外 21 : 761-765, 1998

5）柴崎真澄，七海慶子，蘆野良和ほか：七フルケアし やすいストーマ造設法について一特にストーマ切開 創の大きさについての検討一。日本ストーマ会誌 $11: 13-17,1995$ 


\title{
Surgical Devices for Creating Stomas
}

\author{
H. Shibuya, S. Koide, J. Kurokawa and K. Okita \\ Department of Surgery, Muroran City General Hospital
}

Colostomy with easy self-management and without complication is very important for the quality of life of ostomates.

In consideration of the increase of aged ostomates with spontaneous evacuation, protruded type of the stoma would be better for stoma management. In order to create good stomas, various surgical procedures were tried on skin incision of abdominal wall and length of the colon delivered through stoma wound.

Twenty cases of colostomy were evaluated in this study, and it was found that $2.5 \times 1.5$ $\mathrm{cm}$ (vertical and horizontal diameter) of skin incision of abdominal wall resulted in $2.5 \pm 0.4$ $\mathrm{cm}(\mathrm{M} \pm \mathrm{SE})$, and $3.0 \sim 3.5 \mathrm{~cm}$ of length of the colon resulted in $1.2 \pm 0.6 \mathrm{~cm}(\mathrm{M} \pm \mathrm{SE})$. Thus the operations were satisfactory for creating good stoma. 